\title{
CHARACTERISTICS OF THE AlTiCrN+DLC COATING DEPOSITED WITH A CATHODIC ARC AND THE PACVD PROCESS
}

\author{
ZNAČILNOSTI AITiCrN+DLC PREVLEKE, NANEŠENE S \\ KATODNIM OBLOKOM IN PACVD POSTOPKOM
}

\author{
Krzysztof Lukaszkowicz ${ }^{1}$, Ewa Jonda ${ }^{1}$, Jozef Sondor ${ }^{2}$, Katarzyna Balin ${ }^{3,4}$, \\ Jerzy Kubacki ${ }^{3,4}$ \\ ${ }^{1}$ Institute of Engineering Materials and Biomaterials, Silesian University of Technology, Konarskiego St. 18A, 44-100 Gliwice, Poland \\ ${ }^{2}$ LISS, Dopravni 2603, 75661 Roznov p.R., Czech Republic \\ ${ }^{3}$ A. Chelkowski Institute of Physics, University of Silesia, Uniwersytecka 4, 40-007 Katowice, Poland \\ ${ }^{4}$ Silesian Center for Education and Interdisciplinary Research, University of Silesia, 75 Pulku Piechoty 1A, 41-500 Chorzów, Poland \\ krzysztof.lukaszkowicz@polsl.pl \\ Prejem rokopisa - received: 2014-07-13; sprejem za objavo - accepted for publication: 2015-03-23
}

doi: $10.17222 / \mathrm{mit} .2014 .104$

A coating system composed of the AlTiCrN film covered with diamond-like carbon (DLC)-based lubricant, deposited on a hot-work tool-steel substrate was the subject of the research. The AlTiCrN and DLC layers were deposited with a cathodic arc and the PACVD technology on the X40CrMoV5-1.

A HRTEM investigation showed an amorphous character of the DLC layer. It was found that the tested AlTiCrN layer has a columnar character with fine crystallites. Based on the XRD analysis, the fcc type of the crystal structure was proposed for this layer. Combined studies including SEM, AES and ToF-SIMS confirmed the chemical composition and layered structure of the coating. The chemical distributions of the elements inside the layers and at the interfaces were analyzed with the SEM and AES methods. It was shown that an additional layer of $\mathrm{Cr}$ and AlTiN is present between the substrate and the AlTiCrN coating. In sliding dry-friction conditions, the friction coefficient for the investigated elements is set in the range of $0.02-0.03$. The investigated coating revealed a high wear resistance. The coating demonstrated a good adhesion to the substrate.

Keywords: AlTiCrN film, DLC film, TEM, SEM, AES, ToF-SIMS, chemical composition, tribological properties

Predmet preiskave je bil sestavljen sistem AlTiCrN plasti, pokritih z diamantu podobnim ogljikom (DLC)- kot mazivom, ki je bil nanešen na podlago iz orodnega jekla, za delo v vročem. AlTiCrN in DLC plasti so bile nanešene s tehnologijo katodnega ARC in PACVD na X40CrMoV5-1.

HRTEM-preiskava je pokazala amorfne značilnosti DLC plasti. Ugotovljeno je bilo, da ima preiskovana plast AlTiCrN stebrasta drobna kristalna zrna. Na osnovi XRD analize je za to plast predlagana ploskovno centrirana kubična (fcc) kristalna zgradba. Kombinirane SEM, AES in ToF-SIMS študije so potrdile kemijsko sestavo in plasti v zgradbi nanosa. Razporeditev kemijskih elementov v plasteh in na stiku je bila analizirana s SEM in AES metodami. Ugotovljeno je, da je dodatna plast Cr in AlTiN prisotna med podlago in AlTiCrN nanosom. Pri pogojih suhega drsenja je bil koeficient trenja postavljen $\mathrm{v}$ območje med $0,02-0,03$. Preiskovan nanos je pokazal veliko odpornost na obrabo in dobro oprijemljivost na podlago.

Ključne besede: plast AlTiCrN, plast DLC, TEM, SEM, AES, ToF-SIMS, kemijska sestava, tribološke lastnosti

\section{INTRODUCTION}

Rapid advancements in modern industries, including plastic fabrication, mostly depend on the capabilities of the surface engineering. ${ }^{1,2}$ A wide range of the currently available types of coatings and deposition technologies is a result of a growing demand, in the recent years, for modern-material surface-modification and protection methods. Currently, from among a myriad of the techniques enhancing the tool life, the CVD (chemical vapour deposition) and PVD (physical vapour deposition) methods are playing an important role in industrial practice. ${ }^{3}$ An innovative approach in the surface treatment is the application of hybrid technologies providing a broad range of the types of the associated processes, allowing the fabrication of a whole array of materials with unique properties for precisely defined applications, unachievable with the standard surface-treatment methods. ${ }^{4,5}$

The coatings produced with the PVD technique are recognised as one of the very interesting premium technologies for modifying and protecting tool surfaces, due to the possibility to synthesize the materials with unique chemical and physical properties. One of the most effective and universal coatings of this type is the AlTiCrN hard coating. AlTiCrN coatings were developed for wet and dry machining, as well as forming due to the stability of their mechanical characteristics at elevated temperatures. ${ }^{6,7}$ Diamond-like carbon (DLC) films showed a considerable potential for wear-resistant coatings due their low friction coefficients and a good wear resistance, particularly under dry-friction conditions. Their beneficial tribological properties come from smooth surfaces and good tribochemistry, leading to the 
formation of graphite-rich layers acting as a solid lubricant. $^{8-10}$ DLC films have been produced with various deposition techniques such as PACVD (plasma-assisted chemical vapour deposition), magnetron sputtering, PLD (pulsed-laser deposition) etc.

The aim of this work is to examine the microstructure, mechanical and tribological properties of the AlTiCrN+DLC coating system.

\section{EXPERIMENTAL DETAILS}

The examinations were made on the X40CrMoV5-1 hot-work tool steel covered with the AlTiCrN+DLC coating. The AlTiCrN film was deposited with the cathodic-arc technology (coating machine PLATIT PL1000). Coating depositions were carried out in an $\mathrm{Ar}$ and $\mathrm{N}_{2}$ atmosphere. Cathodes containing pure $\mathrm{Cr}$ and the AlTi alloy (67:33 amount fractions) were used for the coating deposition. To improve the adhesion of the coatings, the $\mathrm{Cr}$ and AlTi cathodes were started to burn and form the $\mathrm{Cr}$ and AlTiN adhesion layer. The DLC topcoat was deposited using acetylene $\left(\mathrm{C}_{2} \mathrm{H}_{2}\right)$ as the gas precursor in a PLATIT $\pi 300+D L C$ unit. The DLC layer was produced with the PACVD. The deposition conditions are summarized in Table 1.

The cross-sections of the deposited coatings were mapped with a SUPRA 35 scanning electron microscope (SEM). Detection of secondary electrons was used for generating fracture images with a $4 \mathrm{kV}$ bias voltage.

Table 1: Coating-deposition parameters

Tabela 1: Parametri nanašanja plasti

\begin{tabular}{|c|c|c|}
\hline Parameter & AlTiCrN & DLC \\
\hline Working pressure $(\mathrm{Pa})$ & 2.5 & 2.0 \\
\hline Substrate bias voltage $(\mathrm{V})$ & -50 & -500 \\
\hline Target current $(\mathrm{A})$ & $\mathrm{Cr}-140$ & - \\
\hline PlTi -120 & 220 \\
\hline
\end{tabular}

The diffraction and thin-film microstructures were tested with a TITAN 80-300 ultrahigh-resolution scanning/transmission electron microscope. The thin crosssection lamellas for TEM observations were prepared with the focused-ion-beam (FIB) technique using a Quanta 200i instrument with gallium ions.

Raman spectroscopy was used to identify the $s p^{3} / s p^{2}$ bond ratio and the chemical bond of the DLC film. Raman measurements were performed at room temperature with an inVia-Raman microscope (Renishaw) with a $514.5 \mathrm{~nm} \mathrm{Ar}^{+}$laser and a resolution of $1 \mathrm{~cm}^{-1}$.

$\mathrm{X}$-ray diffraction studies of the analyzed coatings were carried out on an X'Pert PRO system made by the Panalytical Company using the filter radiation of a cobalt anode lamp. The phase identification of the investigated coatings was carried out in the Bragg-Brentano geometry (XRD) and in the grazing-incidence geometry (GIXRD).
The measurements of the stresses of the analyzed coatings were made with $\sin ^{2} \psi$ on the basis of the X'Pert Stress Plus program. In the method of $\sin ^{2} \psi$ based on the displacement effect of diffraction lines for different $\psi$ angles, appearing in the stress conditions of the materials with a crystalline structure, a silicon strip detector was used at the side of the diffracted beam. The sample inclination angle $\psi$ towards the primary beam was changed in the range of $0^{\circ}-75^{\circ}$.

The layered structure of the coating was tested with a depth-profile measurement performed with the ToFSIMS method. Time-of-flight secondary-ion mass-spectrometry (ToF-SIMS) experiments were performed using a TOF.SIMS 5 (ION-TOF GmbH, Munster, Germany) reflection-type spectrometer equipped with a bismuthliquid metal-ion gun. A focused high-energy primary-ion beam (pulsed $30 \mathrm{keV} \mathrm{Bi}^{+}$ions at an ion current of $\sim 1 \mathrm{pA}$ ) was aimed at the sample surface at an angle of $45^{\circ}$ relative to the surface normal causing the emission of secondary ions. Secondary-ion spectra and distribution maps were collected by rastering the ion beam across areas of $300 \mu \mathrm{m}^{2} \times 300 \mu \mathrm{m}^{2}$ in a $\mathrm{m} / \mathrm{z}$ range of $1-800 \mathrm{u}$. For the depth profiling, an etching $\mathrm{Cs}$ gun $(2 \mathrm{kV}, 100$ nA) was also used in the alternating mode with the analysis bismuth gun. The raster of the analysis beam $\left(300 \mu \mathrm{m}^{2} \times 300 \mu \mathrm{m}^{2}\right)$ was centred inside the etching one $\left(500 \mu \mathrm{m}^{2} \times 500 \mu \mathrm{m}^{2}\right)$.

The chemical composition of the cross-section of the coating was tested with the Auger electron spectroscopy (AES) method. The measurements were carried out with a PHI 5700/660 Physical Electronics spectrometer. A $\mathrm{Xe}^{+}$ion gun was used to create a crater through all the layers of the sample. Then, the obtained crater was analyzed with scanning electron microscopy (SEM) and Auger electrons (AES). The chemical distributions of particular elements in the coating were tested along the selected line across the crater using Auger electrons. The atomic concentration of the main elements of the coating was calculated from the $\mathrm{Al}, \mathrm{Ti}, \mathrm{Cr}, \mathrm{N}, \mathrm{Fe}, \mathrm{O}$ and $\mathrm{C}$ Auger lines using the MULTIPAK software (version 9.5.0.8, Ulvac-phi, Inc.).

The adhesion of the coating to the substrate material was verified with a scratch test on a CSM REVETEST device, by moving the diamond indenter along the examined specimen surface with a gradually increasing load. The tests were made using the following parameters: a load range of $0-100 \mathrm{~N}$, a load-increase rate $(\mathrm{d} L / \mathrm{d} t)$ of $100 \mathrm{~N} / \mathrm{min}$, the indenter sliding speed $(\mathrm{d} x / \mathrm{d} t)$ of $10 \mathrm{~mm} / \mathrm{min}$, and the acoustic-emission detector sensitivity $(A E)$ of 1 . The critical load $L_{\mathrm{C} 2}$, causing a loss in the coating adhesion to the material, was determined on the basis of the values of the acoustic emission $(A E)$ and the recorded friction force $\left(F_{\mathrm{t}}\right)$ as well as the observations of the damage developed during the scratch test on a LEICA MEF4A light microscope.

The friction coefficient and the wear rate of the coating were determined with a ball-on-disc test. The 
tests were carried out on a T-01M (ITE) device with the following parameters: a sliding speed of $0.2 \mathrm{~m} / \mathrm{s}$, a normal load of $20 \mathrm{~N}$, an $\mathrm{Al}_{2} \mathrm{O}_{3}$ counterpart of a $10 \mathrm{~mm}$ diameter, a sliding distance of $1000 \mathrm{~m}$, a temperature of $22{ }^{\circ} \mathrm{C}\left( \pm 1{ }^{\circ} \mathrm{C}\right)$ and a relative humidity of $30 \%( \pm 5 \%)$. To determine the wear rate of the coating $\left(k_{\mathrm{vc}}\right)$ and the wear rate of the counterpart $\left(k_{\mathrm{vb}}\right)$, the procedure proposed by Wänstrand et al. ${ }^{11}$ was used.

\section{RESULTS AND DISCUSSION}

\subsection{Surface and structural studies of the coating}

The cross-section of the investigated coating is presented in Figure 1. The coating presents a compact structure; there is no trace of any coating delamination. The morphology of the DLC layer is characterized by a dense microstructure. A columnar structure is noticed only for the AlTiCrN layer. A clear boundary line is visible between the AlTiCrN and DLC layers. The adhesion layer between AlTiCrN and the steel substrate is not as well defined but still visible on the SEM image. The measured thickness values of the DLC and AlTiCrN layers and the adhesion layer are approximately 1.9, 1.2 and $120 \mathrm{~nm}$, respectively.

Subsequently, for the coating structure characterization, TEM and HRTEM microscopes were used. The images, presented in Figure 2, were obtained from selected regions. The bright-field images (Figure 2a) and the HRTEM micrograph (Figure 2b) show an amorphous character of the DLC films. As expected, the electron-diffraction patterns obtained show a considerable broadening of diffraction rings (the inset image in Figure 2a).

A structural study of the DLC coating was carried out with the Raman spectroscopy. Figure 2c shows a Raman spectrum, decomposed into two Gaussian line shapes. In the current study, the Raman spectra of the DLC layer reveal two broad bands, located at $1403 \mathrm{~cm}^{-1}$ and 1572

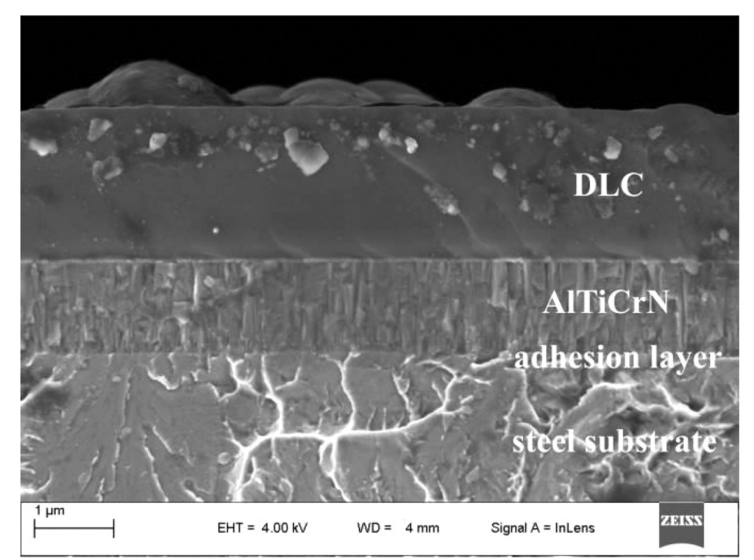

Figure 1: SEM fracture image of the AlTiCrN+DLC coating deposited on the steel substrate

Slika 1: SEM-posnetek preloma AlTiCrN+DLC nanosa na podlagi iz jekla

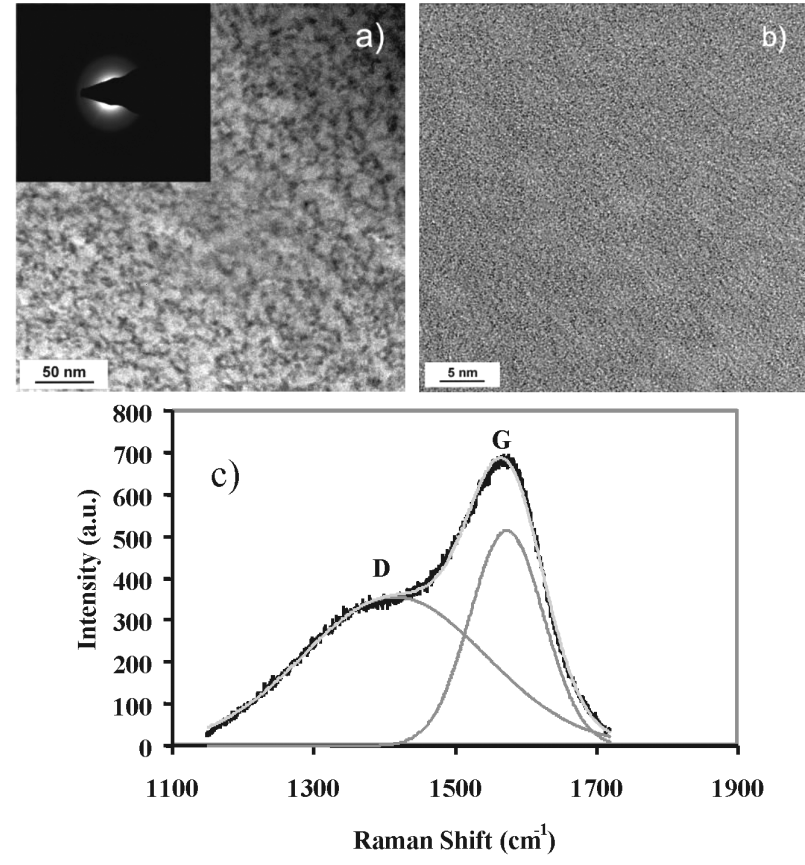

Figure 2: DLC top layer: a) TEM bright-field image and electrondiffraction pattern, b) HRTEM micrograph, c) Raman spectra of DLC layer

Slika 2: DLC vrhnja plast: a) TEM-posnetek svetlega polja in uklon elektronov, b) HRTEM-posnetek, c) Ramanski spektri DLC plasti

$\mathrm{cm}^{-1}$, designated as the $\mathrm{D}$ and $\mathrm{G}$ peaks, respectively, typically observed in diamond-like carbon coatings. ${ }^{12}$

A columnar structure of the AlTiCrN layer was observed (Figure 3a). In addition, it was also found that the

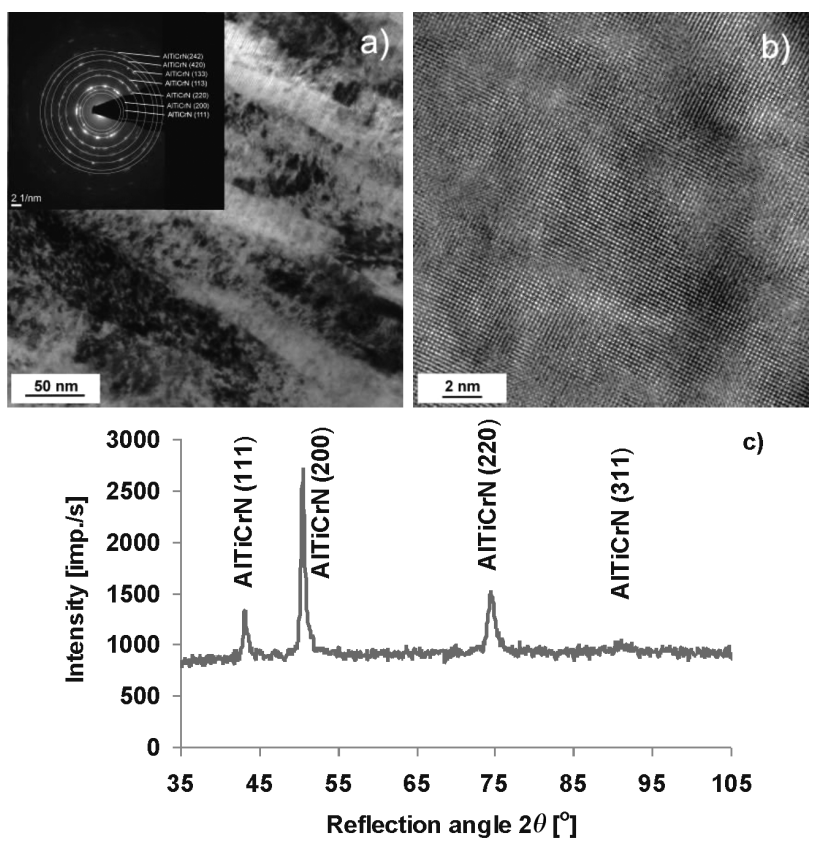

Figure 3: AlTiCrN film: a) TEM bright-field image and electrondiffraction pattern, b) HRTEM micrograph, c) GIXRD spectra at an incidence angle of $\alpha=3^{\circ}$

Slika 3: AlTiCrN nanos: a) TEM-posnetek svetlega polja in uklon elektronov, b) HRTEM-posnetek, c) GIXRD-spektri pri vpadnem kotu $\alpha=3^{\circ}$ 
layer features a compact structure with a high homogeneity (Figure 3b). Fine grains were observed in the big columnar grains of this film, and within one column, the grains are similarly oriented.

On the basis of the results of the GIXRD pattern for the AlTiCrN film, presented in Figure 3c, four reflexes (111), (200), (220) and (311) are shown, corresponding to interplanar spacings of $(0.239,0.207,0.146,0.125)$ $\mathrm{nm}$, respectively, which are characteristic of the $\mathrm{CrN}$ cubic phase. The rate of the intensity of the detected reflexes indicates the presence the fcc-type crystal structure for the AlCrTiN layer.

Two subzones - Cr and AlTiN (Figure 4a) - can be differentiated for the transition zone between the hard AlTiCrN layer and the substrate material. Figure 4b presents the electron-diffraction pattern and HRTEM micrograph obtained for the AlTiN film deposited between the substrate and the AlTiCrN layer.

\subsection{Chemical composition of the coating}

The chemical composition of the coating can be recognized from Figure 5, where the result of the ToF-SIMS depth profile is presented. The distribution of the intensity for $\mathrm{H}^{+}, \mathrm{O}^{+}, \mathrm{N}^{+}, \mathrm{C}^{+}, \mathrm{Ti}^{+}, \mathrm{Cr}^{+}, \mathrm{Al}^{+}$and $\mathrm{Fe}^{+}$ions confirmed a layered structure of the test sample. Three different uniform layers can be distinguished. An analysis of the molecular signals of carbon and hydrogen ions indicates that the first layer can be linked with the outermost hydrogenated DLC layer of the coating. The molecular signals of $\mathrm{C}^{+}$and $\mathrm{H}^{+}$drop rapidly when the second layer containing $\mathrm{Al}, \mathrm{Ti}, \mathrm{Cr}$ and $\mathrm{N}$ is exposed. The second layer corresponds to the PVD-grown AlTiCrN film. The molecular signals of the $\mathrm{Al}^{+}, \mathrm{Ti}^{+}, \mathrm{Cr}^{+}$and $\mathrm{N}^{+}$ ions are roughly constant throughout the width of this layer although, at the interfaces of DLC/AlTiCrN and AlTiCrN/substrate, some changes can be observed in the depth profiles of the selected $\mathrm{Al}^{+}, \mathrm{Ti}^{+}, \mathrm{Cr}^{+}$ions.

Additionally, at the interface of DLC/AlTiCrN a small signal from the oxygen ions was detected. An increase in the counts of $\mathrm{Ti}^{+}, \mathrm{Cr}^{+}$and $\mathrm{Al}^{+}$in the transition
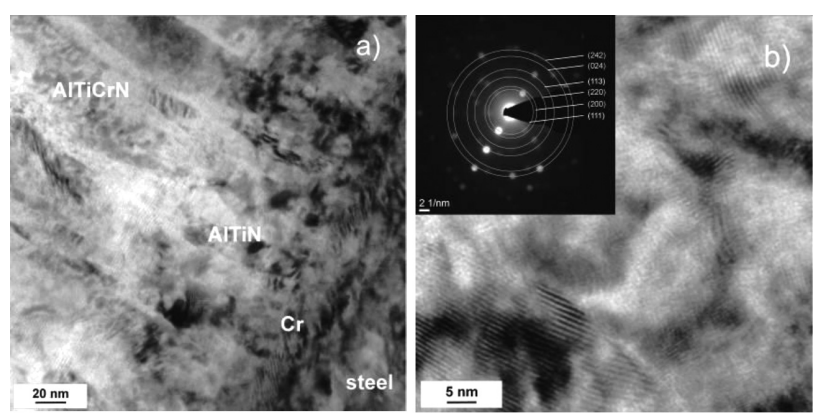

Figure 4: a) Structure of the transition zone between the AlTiCrN layer and substrate material, b) TEM bright-field image and electron-diffraction pattern of the AlTiN interlayer

Slika 4: a) Struktura prehodnega področja med AlTiCrN plastjo in podlago, b) TEM-posnetek svetlega polja in uklona elektronov $v$ AlTiN vmesni plasti zone of DLC is associated with the border-exposure values of the elements at the start of the deposition, suggesting the presence of an additional layer composed of the $\mathrm{Al}, \mathrm{Ti}$ and $\mathrm{Cr}$ atoms. However, the increase in the counts in the transition zone may also be related with the specific conditions of the deposition process. The observed increase in the $\mathrm{Cr}$ counts in the transition region between AlTiCrN and the substrate confirmed the presence of the adhesion layer. However, a clear depth profile of the $\mathrm{Cr}$ signal observed before the visible maximum and the increase in the $\mathrm{Al}$ and $\mathrm{Ti}$ counts suggested the presence of another additional layer, detected in Figure 4a.

In the region of the substrate, the signals of $\mathrm{Fe}$ and $\mathrm{Cr}$ were detected at a stable level. A small signal of carbon was also detected for this part of the tested coating. The small counts observed in the case of the nitrogen ions are a result of a small cross-section of the positive ionization process for the nitrogen ions. The presented analysis of the Tof-SIMS measurement is compared with the AES results in the next section of this article. It is noted that the distribution of the particular elements in the structure of the sample was obtained during the Cs sputtering process in ultra-high vacuum conditions. Hence, it is the real composition of the coating without the presence of adsorbates.

In order to obtain the information about the chemical distribution and atomic concentration of the coating, a study combining SEM and AES was performed. At the beginning, a crater area was obtained using the sputtering method (the sputtering process was described in detail in the experimental-detail section) on all the layers of the coating. The size of the crater was about two millimeters. Next, particular surface parts of the crater area were analyzed with Auger electron spectroscopy (AES).

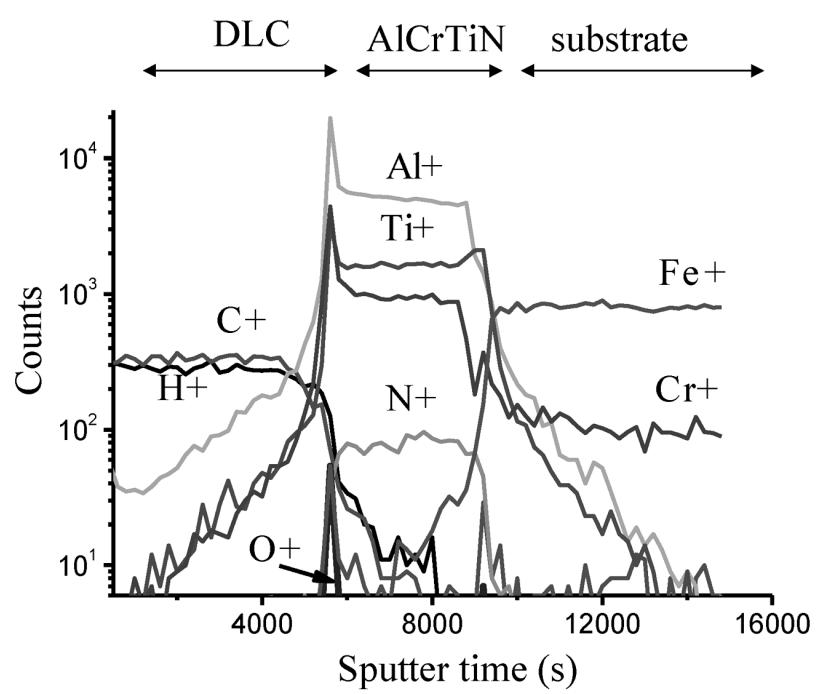

Figure 5: ToF-SIMS depth profile of the tested coating obtained for positive ions

Slika 5: ToF-SIMS globinski profil preiskovanega nanosa s pozitivnimi ioni 
In Figure 6a, a SEM image of the coating interface, obtained with the sputtering process, is presented. Auger differentiation spectra (Figure $6 \mathbf{b}$ ) were obtained from the marked points of the SEM photography. The top spectrum containing only a C KLL signal was detected from the outermost DLC layer. The middle spectrum contains the signals corresponding to the Al KLL, Cr LMM, Ti LMM and N KLL Auger transitions. A small signal of carbon contamination occurred at a kinetic energy of $279 \mathrm{eV}$. The obtained results are in agreement with the ToF-SIMS study, where carbon was also detected in the AlTiCrN layer (Figure 5). The spectrum recorded for the substrate area consists of groups of peaks corresponding to the oxygen and iron Auger transitions. The presence of oxygen in the substrate of the coating is a result of the adsorption process involving the residual gases of the tested sample, taking place during the long measurement. The adsorption process is discussed together with the analysis of the line-profile results.

In Figures 7a and $\mathbf{7 b}$ the results of the chemical distribution of particular elements, detected along the marked line on the attached SEM picture are presented. It should be noted that the $x$-axis on the SEM image and the line-profile curves represent the dimensions in the lateral plane, not in the depth of the coating. Three different areas can be distinguished on the top images in Figures $7 \mathbf{a}$ and $\mathbf{7 b}$. The first, dark region between $0 \mu \mathrm{m}$
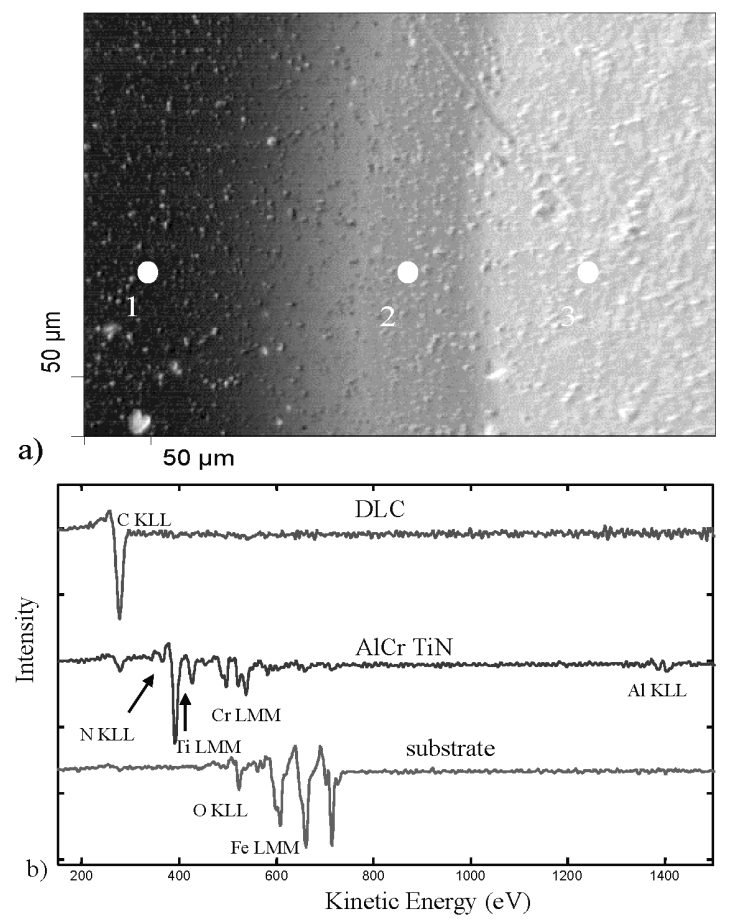

Figure 6: SEM image of the cross-section of the test coating: obtained with the argon-sputtering process. The Auger differentiation spectra, recorded for various parts of the area, are marked as points 1, 2 and 3 . Slika 6: SEM-posnetek prečnega prereza preizkušanega nanosa: pridobljen z jedkanjem z argonom. Augerjevi diferencirani spektri zapisani iz različnih področij so označeni kot točke 1,2 in 3 .
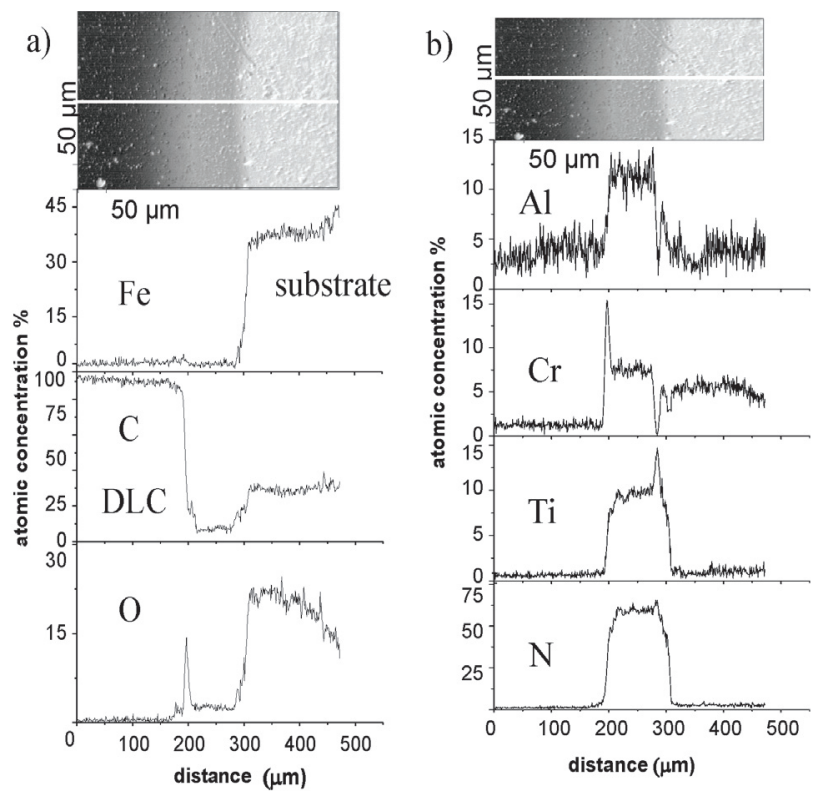

Figure 7: SEM images and chemical distributions of: a) iron, carbon oxygen, b) aluminum, chromium, titanium and nitrogen, at the DLC AlCrTiN - substrate interface

Slika 7: SEM-posnetka in porazdelitev vsebnosti: a) železa, ogljika in kisika ter b) aluminija, kroma, titana in dušika, na stiku med DLC AlCrTiN - podlago

- $200 \mu \mathrm{m}$ represents the DLC film. The next, light-gray area corresponds to the AlTiCrN layer between $200 \mu \mathrm{m}-$ $300 \mu \mathrm{m}$. The last, light region corresponds to the substrate.

The chemical distributions of carbon, oxygen and iron obtained along the marked line are presented in Figure 7a. The concentrations of carbon and oxygen in the DLC region are about $98 \%$ and below $2 \%$, rapidly decreasing to $5 \%$ and $2 \%$ in the AlTiCrN layer, respectively. However, an increase in the oxygen signal to about $15 \%$ is clearly visible at the DLC/AlTiCrN interface. A similar result was obtained with the ToF-SIMS method (Figure 5). The presence of small amounts of carbon and oxygen in the AlTiCrN layer and the steel substrate can be explained as the presence of a thin adsorbate layer on the analyzed surface. This layer was created due to the adsorption of the residual gases from the analysis chamber. The amount of the adsorbate layer increased during the measurement and different parts of the coating had various adhesion coefficients. Hence, the chemical distributions of carbon and oxygen in the substrate area, i.e., the increases in the concentrations observed for these elements are due to the increase in the adsorbate layer and it is not related with the real chemical structure of the substrate.

The distributions of the concentrations of $\mathrm{Al}, \mathrm{Ti}, \mathrm{N}$ and $\mathrm{Cr}$ in the AlTiCrN area are presented in Figure $\mathbf{7 b}$. The levels of atomic concentrations of aluminum, chromium, titanium and nitrogen are almost stable and are about $12 \%, 8 \%, 10 \%$ and $60 \%$, respectively. An increase in the atomic concentration of $\mathrm{Cr}$ to a value of 
$15 \%$ is observed in the transition zone between DLC and AlTiCrN. This suggests that an additional layer of chromium exists in the interface area, i.e., CrN. Increases in the atomic concentrations to $15 \%$ for titanium, to $8 \%$ for aluminum and to $64 \%$ for nitrogen are visible in the transition zone between AlTiCrN and the substrate.

On the other hand, the atomic concentration of chromium in this area rapidly drops to nearly zero. This may be due to the presence of additional layer AlTiN in the interface. Further, the concentration of chromium rapidly jumps from zero to about $5 \%$ in the transition zone, which may suggest the presence of the second additional layer of chromium. Both of these layers may constitute an adhesion layer presented in Figures $\mathbf{1}$ and $\mathbf{4 a}$. In the substrate area, the atomic concentrations of $\mathrm{Al}$, Ti and $\mathrm{N}$ decreased to zero; only a small signal of chromium was detected. These results are in agreement with the data from Figure 5 (Tof-SIMS) where, apart from iron, chromium ions were also recorded on the substrate.

\subsection{Mechanical properties}

The measurements of the stresses within the analysed layers were performed with the $\sin ^{2} \psi$ method. The values of the stresses could only be determined for the AlTiCrN layer due to an amorphous character of the DLC layer. The "negative" slope of the line acquired during the measurements of the stresses indicates that internal compressive stresses exist in the AlTiCrN coating (Figure 8). Depending on their values, the internal stresses may positively or negatively influence the coating/substrate material system, which directly relates to the service life of the tools coated with protective layers. The compressive stresses produced for the analysed layers improve the cracking resistance and enhance the coating adhesion to the substrate. The tensile stresses, though, accelerate the coating-destruction process with an externally load applied.

Critical load values $L_{\mathrm{C} 1}$ and $L_{\mathrm{C} 2}$ were determined using the scratch-test method with a linearly increasing load, characterizing the adhesion of the investigated coatings to the steel substrate. The load at which the first

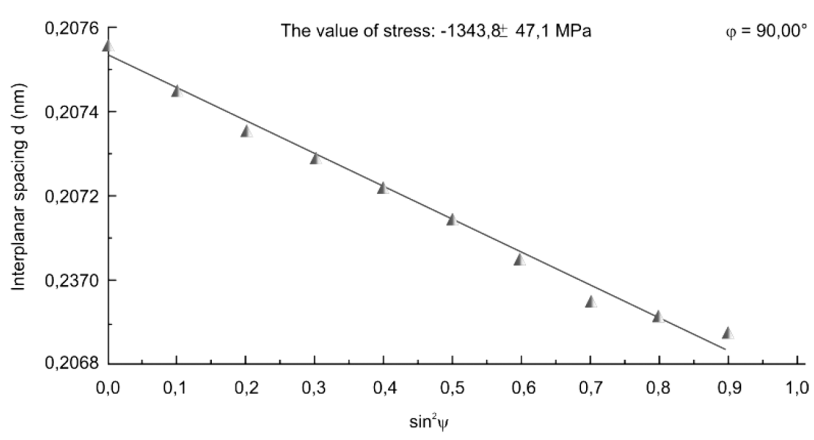

Figure 8: Changes in interplanar-spacing value $d$ of reflex (200) of the AlTiCrN layer in the function of $\sin ^{2} \psi$

Slika 8: Sprememba vrednosti razdalje $d$ odboja (200) plasti AlTiCrN v odvisnosti od $\sin ^{2} \psi$
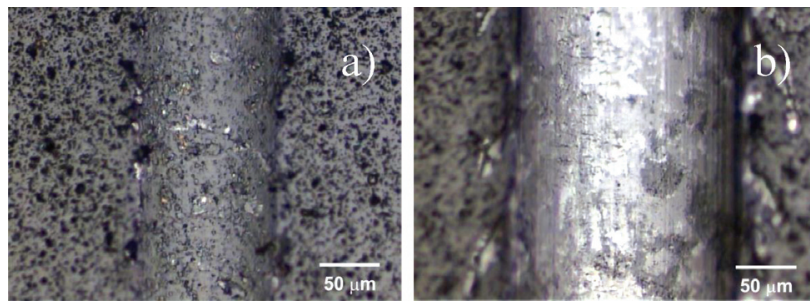

Figure 9: Scratch-failure images of the AlTiCrN+DLC coating at: a) $L_{\mathrm{C} 1}$, b) $L_{\mathrm{C} 2}$

Slika 9: Posnetka raze v AlTiCrN+DLC nanosu pri: a) $L_{\mathrm{C} 1}$, b) $L_{\mathrm{C} 2}$

coating defects appear is known as the first critical load, $L_{\mathrm{C} 1}$. The first critical load, $L_{\mathrm{C} 1}$, corresponds to the point, at which the first damage is observed (Figure 9a); the first appearance of microcracking, surface flaking outside or inside the track without any exposure of the substrate material - the first cohesion - indicates a failure event. The second critical load, $L_{\mathrm{C} 2}$, is the point, at which a complete delamination of the coating starts; the first appearance of cracking, chipping, spallation and delamination outside or inside the track with an exposure of the substrate material - the first adhesion - indicates a failure event (Figure 9b). The investigated coating shows relatively high values of the critical load. The first failure occurs at a value of $\sim 28 \mathrm{~N}$. The second critical load, $L_{\mathrm{C} 2}$, occurs at $67 \mathrm{~N}$.

To determine the tribological properties of the AlTiCrN+DLC coating, an abrasion test under dry-sliding friction conditions was carried out using the ballon-disk method. Figure $\mathbf{1 0}$ presents a graph of friction coefficient $\mu$ including its changes obtained during the wear tests in relation to the $\mathrm{Al}_{2} \mathrm{O}_{3}$ counterpart. The friction curve is in the initial transitional state of an unstabilized course, during which the friction coefficient is reduced along with the growth of the sliding distance until it obtains the stabilized state, which normally occurs after a distance of about $150 \mathrm{~m}$. Under dry-friction conditions, after the wearing-in period, the friction coefficient recorded for the associations tested is sta-

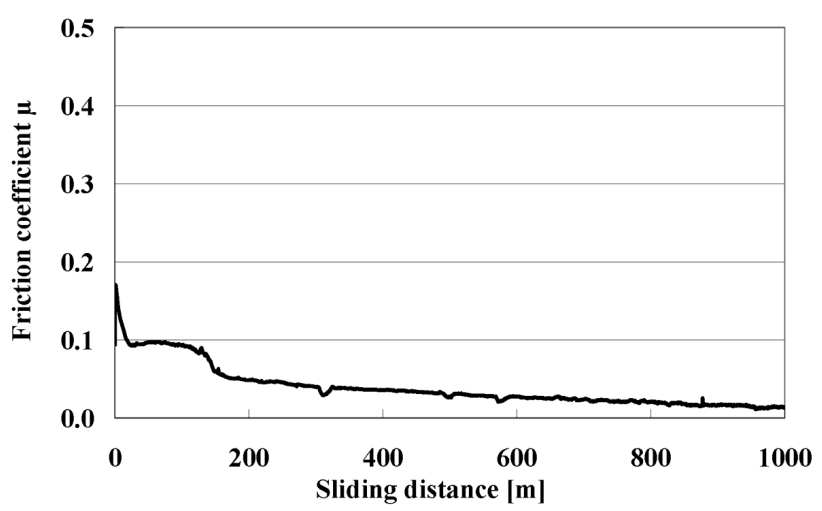

Figure 10: Dependence of the friction coefficient on the sliding distance during the wear test for the AlTiCrN+DLC coating

Slika 10: Odvisnost koeficienta trenja od dolžine poti drsenja med preizkusom obrabe AlTiCrN+DLC nanosa 
bilized in a range of $0.02-0.03$. No case of a complete coating wear-through occurred because the maximum wear-in depths were below the thickness values. The coating and the counterpart examined show a low wear. The values of the wear rate of the coating $k_{\mathrm{vc}}$ and the counterpart $k_{\mathrm{vb}}$ were recorded to be $3.30 \times 10^{-7} \mathrm{~mm}^{3} / \mathrm{N} \mathrm{m}$ and $4.53 \times 10^{-9} \mathrm{~mm}^{3} / \mathrm{N} \mathrm{m}$, respectively. The microhardness of the AlTiCrN film is $3400 \mathrm{HV}$ and the one of the DLC is $1650 \mathrm{HV}$.

\section{CONCLUSION}

The AlTiCrN+DLC coating was successfully deposited on the X40CrMoV5-1 hot-work tool-steel substrate. A columnar microstructure of the coating, without any visible delamination, was observed with the scanning electron microscope. The investigation indicates the occurrence of a transition zone between the substrate material and the coating, which improves the adhesion. This is evidenced by the high values of the critical load $L_{\mathrm{C} 2}$ of the coatings analysed. It was observed that the AlTiCrN film has a nanostructure with fine crystallites. The tests using TEM confirmed an amorphous character of a low-friction DLC layer. A phase-composition analysis of the DLC layer with the Raman-spectroscopy method showed the presence of bonds distinctive for diamond $\left(s p^{3}\right)$ and graphite $\left(s p^{2}\right)$, typically observed in diamond-like carbon coatings. Under dry-friction conditions, the friction coefficient for the associations tested is within a range of $0.02-0.03$ for the investigated coating. According to the XRD pattern of AlTiCrN, fcc phases only occurred in the coating. Negative (compressive) internal stresses exist in the tested coating, substantially influencing the growth of tribological and strength properties, including the coating adhesion to the substrate. A chemical-composition analysis carried out with the AES method revealed an equilibrium concentration of nitride and metallic elements forming the AlTiCrN layer. The DLC film is composed of carbon and hydrogen.

\section{REFERENCES}

${ }^{1}$ T. W. Scharf, S. V. Prasad, Solid lubricants: a review, Journal of Materials Science, 48 (2013), 511-531, doi:10.1007/s10853-0127038-2

${ }^{2}$ P. Jurči, J. Bohovičová, M. Hudáková, P. Bílek, Characterization and wear performance of $\mathrm{CrAgN}$ thin films deposited on $\mathrm{Cr}-\mathrm{V}$ ledeburitic tool steel, Mater. Tehnol., 48 (2014) 2, 159-170

${ }^{3}$ S. Veprek, M. J. G. Veprek-Heijman, Industrial applications of superhard nanocomposite coatings, Surface \& Coatings Technology, 202 (2008), 5063-5073, doi:10.1016/j.surfcoat.2008.05.038

${ }^{4}$ A. A. Voevodin, J. S. Zabinski, Nanocomposite and nanostructured tribological materials for space applications, Composites Science and Technology, 65 (2005), 741-748, doi:10.1016/j.compscitech.2004. 10.008

${ }^{5}$ D. Yu, C. Wang, X. Cheng, F. Zhang, Microstructure and properties of TiAlSiN coatings prepared by hybrid PVD technology, Thin Solid Films, 517 (2009), 4950-4955, doi:10.1016/j.tsf.2009.03.091

${ }^{6}$ D. V. Shtansky, P. V. Kiryukhantsev-Korneev, I. A. Bashkova, A. N. Sheveiko, E. A. Levashov, Multicomponent nanostructured films for various tribological applications, International Journal of Refractory Metals \& Hard Materials, 28 (2010), 32-39, doi:10.1016/j.ijrmhm. 2009.07.014

${ }^{7}$ A. Alberdi, M. Marin, B. Diaz, O. Sanchez, R. Escobar Galindo, Wear resistance of titanium-aluminium-chromium-nitride nanocomposite thin films, Vacuum, 81 (2007), 1453-1456, doi:10.1016/ j.vacuum.2007.04.024

${ }^{8}$ S. Zhang, X. L. Bui, Y. Fu, H. Du, Development of carbon-based coating of extremely high toughness with good hardness, International Journal of Nanoscience, 3 (2004), 571-578, doi:10.1142/ S0219581X04002395

${ }^{9}$ K. W. Weng, S. Han, Y. C. Chen, D. Y. Wang, Characteristics of diamond-like carbon film deposited by filter arc deposition, Journal of Materials Processing Technology, 203 (2008), 117-120, doi:10.1016/j.jmatprotec.2007.09.061

${ }^{10}$ K. Lukaszkowicz, A. Czyzniewski, W. Kwasny, M. Pancielejko, Structure and mechanical properties of PVD coatings deposited onto the X40CrMoV5-1 hot work tool steel substrate, Vacuum, 86 (2012), 1186-1194, doi:10.1016/j.vacuum.2011.10.031

${ }^{11}$ O. Wänstrand, M. Larsson, P. Hedenqvist, Mechanical and tribological evaluation of PVD WC/C coatings, Surface and Coatings Technology, 111 (1999), 247-254, doi:10.1016/S0257-8972(98) 00821-4

${ }^{12}$ J. Robertson, Diamond-like amorphous carbon, Materials Science and Engineering R, 37 (2002), 129-281, doi:10.1016/S0927-796X (02)00005-0 